\title{
Evaluation of broiler dark house illumination systems, with and without thermal
}

\section{insulation}

\author{
Avaliação de sistemas de iluminação de aviários dark house, com e sem isolamento térmico \\ Evaluación de sistemas de iluminación para aviarios dark house, con y sin aislamiento térmico
}

\begin{abstract}
In the breeding of broiler house, the proper use of lighting systems has great influence on the welfare and the productivity of the birds. The objective was to evaluate two artificial lighting systems used in broiler house in terms of the allocative efficiency of luminance. One of the broiler house was closed with black raffia bag (dark house), without thermal insulation (NTI) and its lighting was composed of incandescent, compact fluorescent light (LFCs) and light emitting diode (LED) bulbs. The other broiler house was closed with extruded polystyrene panels (XPS) and thermally insulated (TI), and its lighting was composed of compact fluorescent lamps. The influence of external light of sun inside the broiler house was analyzed by means of exhaust holes and the degree of distribution of illumination through statistical analyzes and the study of the distribution uniformity coefficient (DUC). Contour maps were prepared showing the degree of internal luminance distribution for each broiler house, specifically in the area that did not suffer interference from external natural sunlight. The results showed that natural lighting influenced the internal lighting across the last 18 meters at the end of the broiler house and there was a more homogeneous lighting in the broiler house TI.
\end{abstract}

Keywords: Electric energy; Closing curtains; Natural lighting.

\section{Resumo}

$\mathrm{Na}$ criação de frangos de corte o uso adequado de programas de iluminação é um fator que influencia diretamente o bem-estar e a produtividade das aves. Assim, o objetivo deste trabalho foi avaliar dois sistemas de iluminação artificial utilizados em aviários de frango de corte, quanto à sua eficiência distributiva de iluminamento. Um dos aviários foi fechado com sistema convencional de lona de ráfia escura (Dark house), sem isolamento térmico (N.ISO) e seu sistema de iluminação foi composto por lâmpadas incandescentes, fluorescente compacta e led. O outro aviário foi fechado com isopainéis de poliestireno extrudado (XPS), e isolado termicamente (ISO) e seu sistema de iluminação foi composto somente por lâmpadas fluorescente compacta. Foram analisados o alcance da influência da 
luz solar externa para o interior do aviário, por meio dos exaustores, e o grau de distribuição da iluminação nos aviários por meio de análises estatísticas e do estudo do coeficiente de uniformidade de distribuição (CUD). Foram elaborados mapas de isolinhas mostrando o grau de distribuição de iluminância interna para cada aviário, especificamente na área que não sofreu interferência da iluminação solar natural externa. Os resultados mostraram que a iluminação solar natural externa influenciou a iluminação interna ao longo dos últimos 18 metros no final do aviário e a iluminação foi mais homogênea no aviário ISO.

Palavras-chave: Energia elétrica; Cortinas de fechamento; Iluminação natural.

\section{Resumen}

Al criar pollos de engorde, el uso adecuado de los programas de iluminación es un factor que influye directamente en el bienestar y la productividad de las aves. Así, el objetivo de este trabajo fue evaluar dos sistemas de iluminación artificial utilizados en aviarios de pollos de engorde, en cuanto a su eficiencia de iluminación distributiva. Uno de los aviarios se cerró con un sistema convencional de lona de rafia oscura (Dark house), sin aislamiento térmico (N.ISO) y su sistema de iluminación consistió en lámparas incandescentes, fluorescentes compactas y LED. La otra casa se cerró con isopaneles de poliestireno extruido (XPS), y se aisló térmicamente (ISO) y su sistema de iluminación estaba compuesto únicamente por lámparas fluorescentes compactas. Se analizó la extensión de la influencia de la luz solar externa al interior de la vivienda, a través de los extractores, y el grado de distribución de la iluminación en las viviendas mediante el análisis estadístico y el estudio del coeficiente de uniformidad de distribución (CUD). Se elaboraron mapas de isolíneas que muestran el grado de distribución de iluminancia interna de cada vivienda, concretamente en la zona que no sufrió interferencias de la luz solar natural externa. Los resultados mostraron que la luz solar natural externa influyó en la iluminación interior durante los últimos 18 metros al final de la casa y la iluminación fue más homogénea en la casa ISO.

Palabras clave: Energia electrica; Cortinas de cierre; Iluminacion natural.

\section{Introduction}

The brightness of the environment has been proven to affect behavior, physiology, and welfare of broiler house (Classen et al., 2004; Rutz, \& Bermudez, 2004; Olanrewaju et al., 2006; Kristensen et al., 2007; Lewis et al., 2007; Castellini et al., 2012; Deep et al., 2012; González-Garcia et al., 2014). These birds are kept in rooms with artificial lighting that differs from natural daylight in terms of color, intensity and photoperiod (Gou \& Cherry, 2004; Lewis et al., 2004; Alvino et al., 2009) and intermittency (Vercellino, 2013).

Cao et al. (2008) and Mendes et al. (2010) have shown that light intensity does affect the performance of the broiler. Thus, the adequate distribution of light bulbs inside the broiler house is one of the main factors for the chickens to reach their productive potential obtaining a higher economic performance of the activity (Moraes et al., 2008; Cordeiro et al., 2010).

The level of luminance for broiler house should be the minimum required to allow the birds to identify and move towards the sources of food and water. According to Mendes et al. (2008), this level of luminance should be around eye-level for the chickens and should reach $20 \mathrm{~lx}$ for the first 7 days of life and $5 \mathrm{~lx}$ thereafter.

Modern lighting systems are more energy-efficient and can provide even more appropriate illumination, besides the reduction of electric energy (Cotta, 2002). This has required further research in the entire lighting management system for growing broiler house (Rierson, 2008).

Incandescent light bulbs require low cost in production and are extremely inefficient energetically because only about $5 \%$ of the energy input is converted into visible light, the rest is turned into heat (Aie, 2009).

The advantages of compact fluorescent light bulbs (LFCs) are mainly in the fact that they have the same light output with lower power consumption, which generates energy savings of up to $97 \%$, longer life, in addition to enabling good color definitions (Araujo et al., 2011).

Light Emitting Diode (LED) offers a series of advantages through their technological development, which has made them an actual alternative to replace conventional bulbs. LED technology is being produced with ever lower costs but also has a higher price than incandescent and fluorescent light bulbs (Araujo et al., 2011). 
Regardless of the lighting technology used in the barns, it is important that the lighting is as homogeneous as possible. That provides the producer with the maximum production with minimum energy consumption and feed consumption by birds (Freitas et al., 2005).

Tools such as geostatistical variability can assist in study about the variability of this type of lighting within the farms.

Geostatistics allows the interpretation of the results based on the structure of its natural variability, describing the spatial behavior of the data (Vieira, 2000; Gomes et al., 2007).

Geostatistics also allow us to evaluate the spatial variability in luminance levels in barns through interpolation, with particular emphasis on the use of kriging. This method allows for contour maps of the spatial distribution of the factor under study, aiding in the understanding of the phenomenon (Miragliotta et al., 2006; Faria et al., 2008; Yanagi Junior et al., 2011; Pereira et al., 2012; Curi et al., 2014).

Within the field of irrigation, the Distribution Uniformity Coefficient (DUC) is commonly used to determine the degree of uniformity in water distribution generated by irrigation systems. The method for calculating DUC was proposed by the Soil Conservation Service in 1968 (Drumond et al., 2006).

The DUC can be described as the average of the $25 \%$ lowest precipitation values in relation to the total, or the ratio of the average lowest quartile and the average depth (Paulino et al., 2009).

In the study of lighting systems for poultry barns, the DUC can be used as an analysis tool to determine the luminance distribution uniformity of the lighting system (Inmetro, 2015) installed in the barn, replacing the precipitating factor with the observed luminance.

The objectives of this study were to analyze the uniformity of internal luminance distribution in two dark house poultry barns, checking if these uniformities were influenced by natural external lighting of the sun entering through the operating exhaust fans, and whether the luminance level of the poultry barns met the poultry requirements described in academic literature.

\section{Materials and Methods}

\subsection{Experimental area}

The study was conducted in two air-conditioned poultry barns of the dark house style, located in the region of Palotina - PR. The city of Palotina - PR is located at the coordinates, latitude S $24^{\circ} 12^{\prime}$ and longitude W $53^{\circ} 50^{\prime} 30^{\prime \prime}$ and the climate is subtropical.

\subsection{Characterization of broiler house}

The work was based on the distribution uniformity coefficient methodology proposed by Criddle et al. (1956).

Two broiler houses measuring $15 \times 150 \mathrm{~m}$ each were evaluated.

The structural design of both broiler house object of this study is similar, being composed of 32 precast concrete posts and galvanized steel shell structure covered with aluminum metal roofing.

The broiler house differs in terms of the materials used as side closures and thermal insulation.

The side closure of one of the broiler house was made of raffia curtains, externally gray and internally black. The color of the inner lining is black, being at a height of $2.5 \mathrm{~m}$ in relation to the broiler house floor. This broiler house is not equipped with any materials that increase the thermal insulation between the inside and outside environments and was called not thermally insulated (NTI).

The side closures of the other broiler house are made of extruded polystyrene panels (XPS). The inner lining is made of raffia and in yellow color, at a height of $2.5 \mathrm{~m}$ in relation to the broiler house floor. This broiler house is equipped with 
thermal insulating materials and was called thermally insulated (TI).

\subsection{Analyzed variables}

In order to take the measurements for the level of luminance in the broiler house, were used a digital luximeter of the Instrutherm brand, THDL-300 model.

By means of the luximeter function, readings were taken at 306 points distributed in $3.0 \times 3.0 \mathrm{~m}$ grids within the broiler house, as well as around the sides of the broiler house. On the set measuring points, the device was placed at a height of $0.3 \mathrm{~m}$, simulating the eye-level of the birds before slaughter age.

At the time when this data collection was done, there was still natural outdoor lighting coming from the sunlight. The broiler house had their ventilation systems (exhausts) working properly. Daylight was coming in through the back of broiler house through the exhaust openings.

With the aim of verifying the internal range level of natural light from the sun coming in through the exhaust openings, we have analyzed the internal light distribution in seven different length measurements, always starting from the frontal section towards the length under analysis. Were analyzed $150 \mathrm{~m}$ sections (the entire broiler house), 144, 138, 132, 126, 120 and $114 \mathrm{~m}$, and these were considered as treatments I (control), II, III, IV, V, VI and VII, respectively. The illuminance measurements were performed every 6 meters, as can be observed in Figure 1.

Figure 1. Dimensions for the treatments' sections.

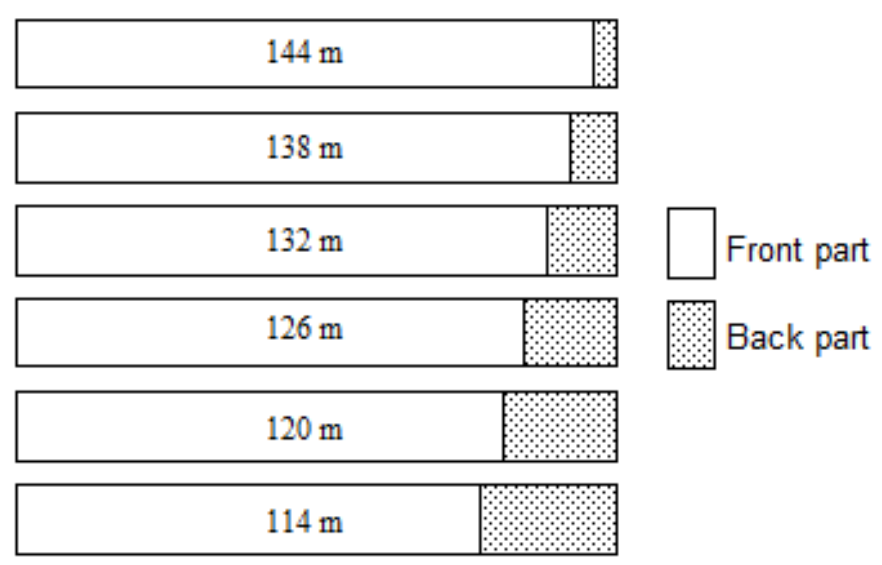

Source: Authors.

\subsection{Statistical analysis}

The statistical analysis was a multifactorial of $2 \times 7$, with seven treatments and two replications. The treatment was the size of broiler house area and repetitions were NTI and TI.

By means of descriptive statistical analysis tools, were calculated the average luminance in lux, standard deviation (SD) and the distribution uniformity coefficient (DUC) for the treatments.

To evaluate the uniformity of luminance distribution, were used the DUC (\%) coefficient by analyzing the relationship between the first quartile and the average luminance for each treatment.

Based on the data were collected; we have created luminance contour maps using the Surfer 12 software. 


\section{Results and Discussion}

\subsection{Internal lighting of broiler house}

Data collection was conducted on February 9th, 2016, between 5:30 PM and 7:30 PM. At the time, the age of the birds was 28 days.

As there was natural outside sunlight entering the aviary through the exhaust running in the back of the broiler house, were analyzed the distribution of internal luminance for each treatment.

The mean lighting (lux), the standard deviation (SD) and the distribution uniformity coefficient (DUC) of the TI and NTI broiler house treatments were calculated. Table 1 shows the statistical descriptive values and the DUC for the broiler house NTI and TI.

Table 1. Luminance values (Lx) for the broiler houses NTI and TI.

\begin{tabular}{cccccccc}
\hline Treatment & $\mathrm{n}$ & \multicolumn{2}{c}{ Average } & \multicolumn{3}{c}{ SD } & \multicolumn{2}{c}{ DUC } \\
\cline { 3 - 8 } & & NTI & TI & NTI & TI & NTI & TI \\
\hline II & 306 & 12.67 & 14.42 & 22.08 & 8.95 & 25.73 & 41.24 \\
II & 294 & 9.15 & 14.05 & 9.02 & 7.99 & 35.63 & 42.89 \\
III & 282 & 7.91 & 13.56 & 4.60 & 6.70 & 39.50 & 43.72 \\
IV & 270 & 7.87 & 13.48 & 4.62 & 6.57 & 39.61 & 44.52 \\
V & 258 & 8.01 & 13.66 & 4.63 & 6.59 & 40.13 & 44.93 \\
VI & 246 & 8.28 & 13.91 & 4.57 & 6.57 & 43.83 & 45.92 \\
VII & 234 & 8.31 & 13.87 & 4.62 & 6.63 & 43.25 & 45.59 \\
\hline
\end{tabular}

Note. $\mathrm{SD}=$ standard deviation; $\mathrm{DUC}=$ distribution uniformity coefficient; NTI $=$ without thermal insulation; $\mathrm{TI}=$ thermally insulated Source: Authors

The standard deviation values showed a similar trend for both broiler houses for the analysis of treatment III. Thus, treatment III was considered the treatment from which there is no influence on the internal illumination caused by natural sunlight.

Figures 2 and 3 shows the graphs of the mean lighting, standard deviation and distribution uniformity coefficient referring to the lighting in the broiler house NTI and TI, respectively, of treatment III onwards. 
Figure 2. Lighting and standard deviation results of broiler houses NTI and TI.

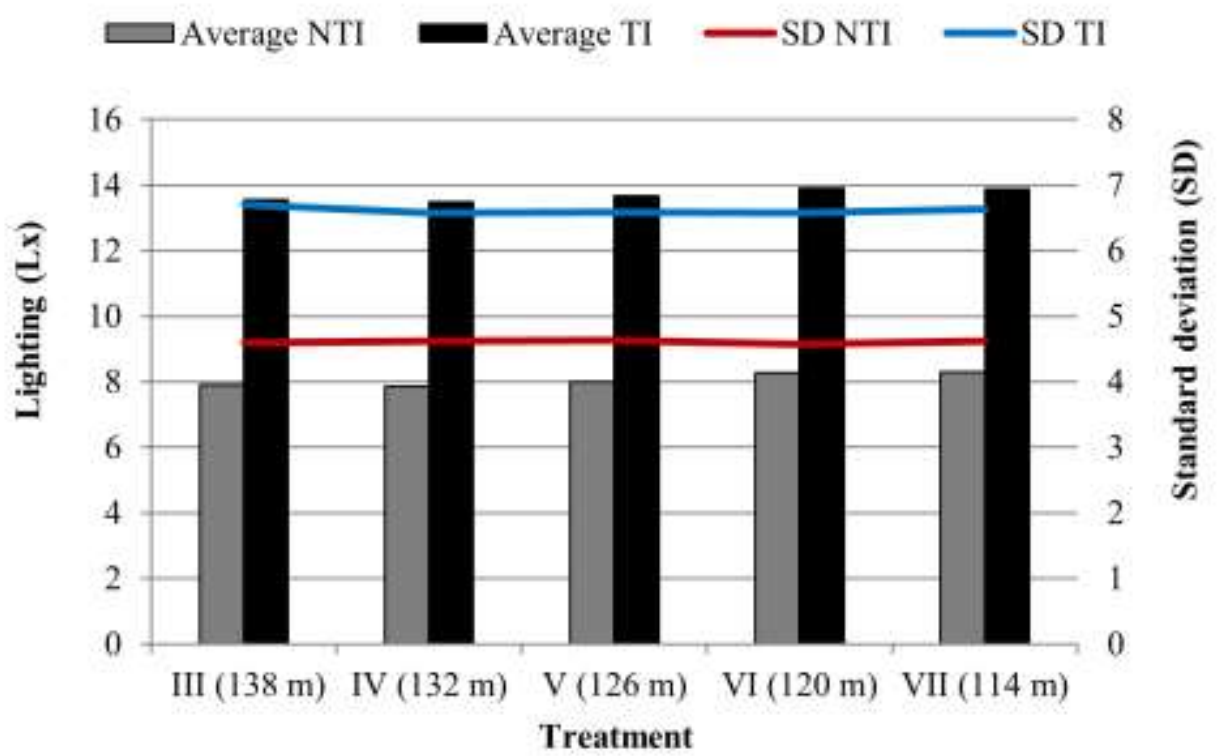

Source: Authors.

Figure 3. Distribution uniformity coefficient results of broiler houses NTI and TI.

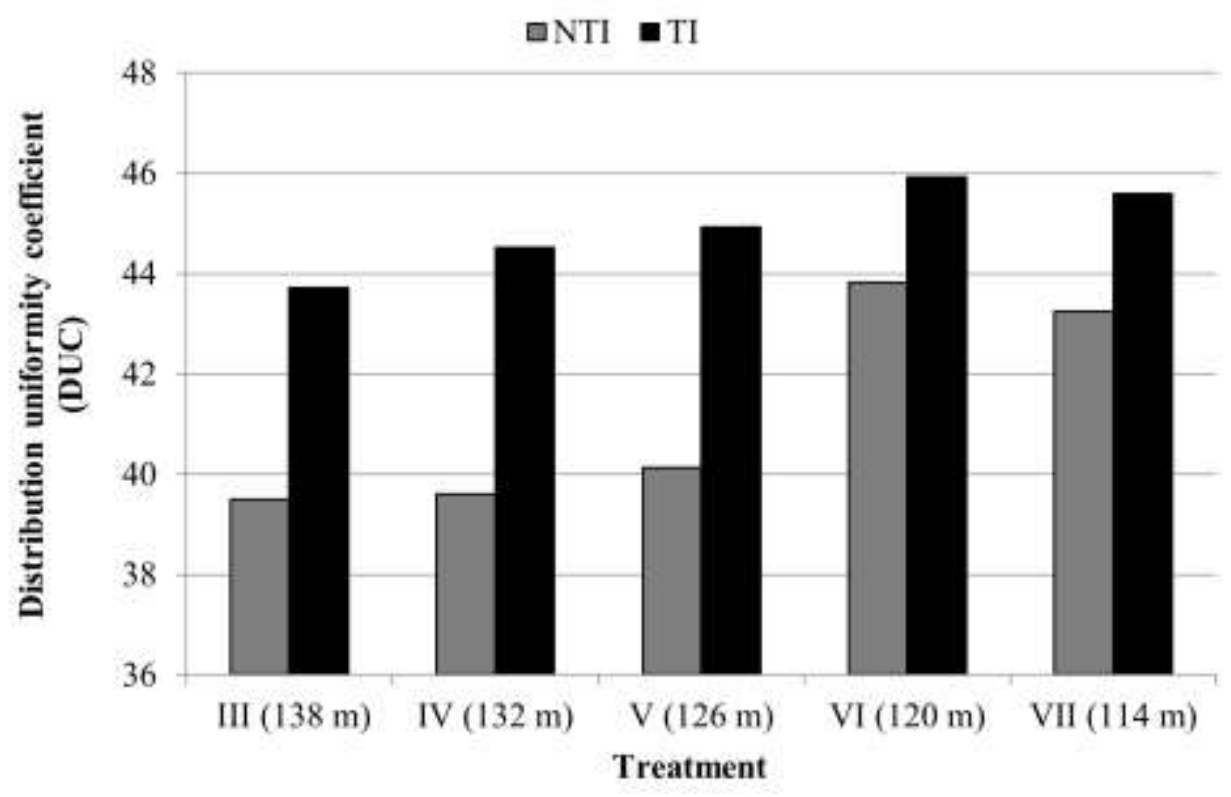

Source: Authors.

\subsection{Luminance contour maps (Lx)}

Based on the knowledge of the luminance values for the NTI and TI barn, we generated the luminance contour maps (Lx) for the broiler houses, which are shown in Figure 4 (a) and 4 (b). 
Figure 4. Contour maps for lux distribution in the broiler houses NTI (a) and TI (b).

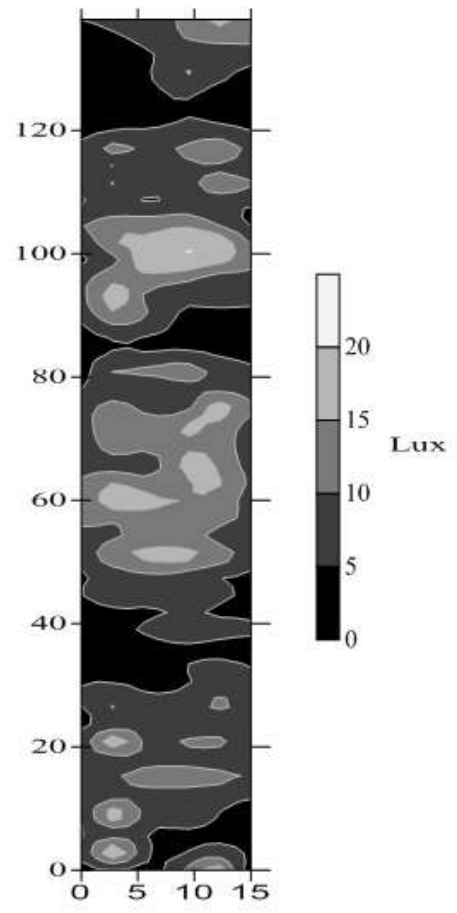

(a)

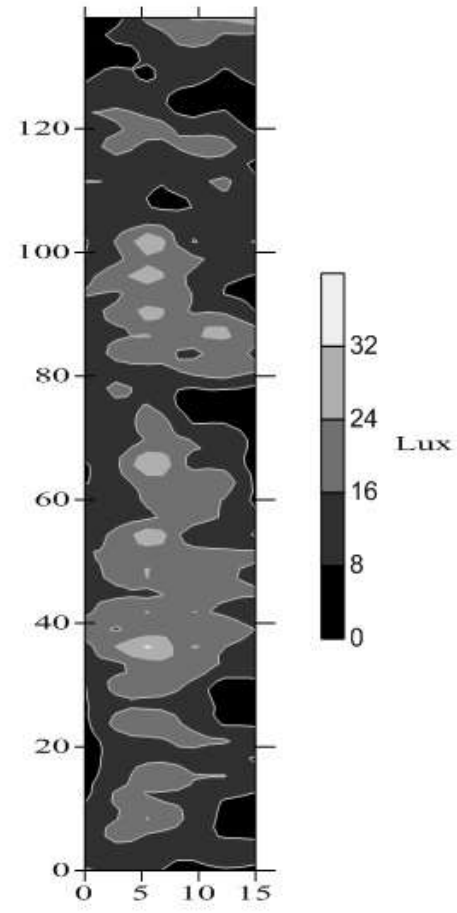

(b)

Source: Authors.

In the map shown in Figure 4 (a), the luminance range from 0 to 5 lx corresponds to the areas where the farmer still uses incandescent bulbs of $60 \mathrm{~W}$ each. These results corroborate Mendes et al. (2008) who state that from 7 days of age chickens may be at this level of luminance. Deep et al. (2012) when studying the impact of light intensity (1, 10, 20 and 40 lx) on behavior and diurnal rhythms of broilers affirm that the birds exposed to a light intensity of 1 lx rested more and indicating a reduced welfare state.

Other areas are places where the farmer installed compact fluorescent or LED light bulbs, as with the need to replace burned incandescent bulbs, the farmer struggles to find incandescent bulbs easily available.

The lighting distribution map in lux for the TI broiler houses is shown in Figure 4 (b). In this broiler houses there were only $25 \mathrm{~W}$ compact fluorescent light bulbs.

In the TI broiler houses there were installed 90 compact fluorescent lamps of $25 \mathrm{~W}$, totaling an installed power of illumination of $2.25 \mathrm{~kW}$.

In the NTI broiler houses, there were 55 installed incandescent lamps of $60 \mathrm{~W}$ each, 32 fluorescent light bulbs of 25 W each and 3 LED $10 \mathrm{~W}$ light bulbs, with a total installed lighting capacity of $4.13 \mathrm{~kW}$.

Although the broiler houses were built with the so-called dark house technology, external natural sunlight can enter the sheds through the exhaust openings and influence the internal luminance distribution of the broiler house from the 18-meter back of the shed.

The analysis of the lighting systems used in the studied broiler houses showed that the broiler houses TI, only equipped with compact fluorescent bulbs of $25 \mathrm{~W}$ each, resulted in more uniform luminance compared to the broiler houses NTI, which had three different technologies of bulbs installed. 
This better distribution does not result in the qualitative affirmation of this feature of distribution. The distribution uniformity coefficients varied from $41.24 \%$ to $45.59 \%$ and from $25.73 \%$ to $43.83 \%$ respectively for the broiler houses $\mathrm{TI}$ and NTI.

The zootechnical indexes for growth of chickens up to the age of 28 days (4th week), are presented in Figure 5.

Figure 5. Weight gain of chickens up to the age of 28 days (4th week).

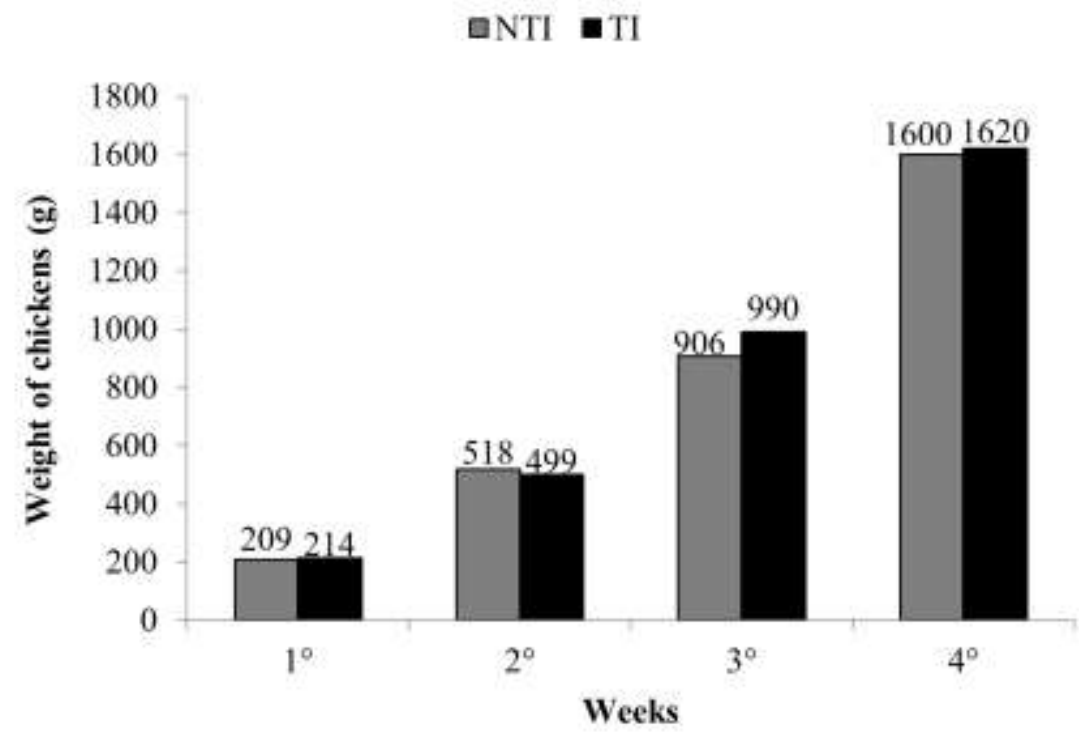

Source: Authors.

The weight gain of the chickens in broiler house NTI and TI were similar, showing the weight gain each week.

\section{Conclusion}

Even with the aviaries being built with dark house technology, the Sun's natural external lighting can enter the aviaries by means of exhaust fans and influence the distribution of internal illuminance of the sheds in the last 18 meters at the bottom of the aviary (the last two spans).

The analysis of the lighting systems used in the study aviaries showed that the TI aviary, equipped only with $25 \mathrm{~W}$ compact fluorescent lamps, obtained a more uniform illumination when compared to the NTI aviary, which had three lamp technologies installed.

It is suggested for future work to evaluate the lighting system using the CUC (Christiansen Uniformity Coefficient) and compare the results with the DUC (Distribution Uniformity Coefficient) for lighting systems.

\section{References}

Agência Internacional de Energia. AIE. (2010). Phase out of incandescent lamps - Implications for international supply and demand for regulatory compliant lamps. Paris. http://dx.doi.org/10.1787/5kmh3nhp62s0-en.

Alvino, G. M., Archer, G. S., \& Mench, J. A. (2009). Behavioural time budgets of broiler chickens reared in varying light intensities. Applied Animal Behaviour Science, 118 (1), 54-61. 10.1016/j.applanim.2009.02.003

Araujo, W. A. G., Albino, L. F. T., Tevernari, F. C., \& Gody, M. J. S. (2011). Programa de luz na avicultura de postura. Avicultura Industrial, 52, 58-65. https://ainfo.cnptia.embrapa.br/digital/bitstream/item/42481/1/Paginas-de-CFMV-52.pdf

Cao, J., Liu, W., Wang, Z., Xie, D., Jia, L., \& Chen, Y. (2008). Green and blue monochromatic lights promote growth and development of broilers via stimulating testosterone secretion and myofiber growth. Journal of Applied Poultry Research, 17 (2), 211-218. 10.3382/japr.2007-00043 
Castellini, C., Boggia, A., Crtina, C., Dal Bosco, A., Paolotti, L., Novelli, E., \& Mugnai, C. (2012). A multicriteria approach for measuring the sustainability of diferente poultry production systems. Journal of Cleaner Production, 37, 192-201. 10.1016/j.jclepro.2012.07.006

Classen, H. L., Annett, C. B., Schwean-Lardner, K. V., Gonda, R., \& Derow, D. (2004). The effects of lighting programmes with twelve hours of darkness per day provided in one, six or twelve hour intervals on the productivity and health of broiler chickens. British Poultry Science, 45, 31-32. $10.1080 / 00071660410001698137$

Cordeiro, M. B., Tinôco, I. F. F., Silva, J. N., Vigoderis, R. B., Pinto, F. A. C., \& Cecon, P. R. (2010). Thermal comfort and performance of chicks submitted to different heating systems during winter. Revista Brasileira de Zootecnia, 39 (1), 217-224. 10.1590/S1516-35982010000100029

Cotta, J. T. B. (2002). Galinha: produção de ovos. Viçosa: Aprenda Fácil, 260p.

Criddle, W. D., Davis, S., Pair, C. H., \& Shockley, D. G. (1956). Methods for evaluating irrigation systems. Washington DC: Soil Conservation Service USDA, 24p. Agricultural Handbook, 82.

Curi, T. M. R. de C., Vercellino, R. do A., Massari, J. M., Souza, Z. M., \& Moura, D. J. de, (2014). Geostatistic to evaluete the environmental control in different ventilation systems in broiler houses. Engenharia Agrícola, 34 (6), 1062-1074. 10.1590/S0100-69162014000600004

Deep, A., Schwean-Laedner, K., Crowe, T. G., Fancher, B. I., \& Classen, H. L. (2012). Effect of light intensity on broiler behaviour and diurnal rhythms. Applied Animal Behaviour Science, 136 (1-15), 50-56. 10.1016/j.applanim.2011.11.002

Drumond, L. C. D., Zanini, J. R., Fernandes, A. L. T., \& Rodrigues, G. P. (2006). Superficial and subsuperficial distribution uniformity of water and wastewater of swine applied by net-sprinkler irrigation system. Engenharia Agrícola, 26 (2), 415-425. 10.1590/S0100-69162006000200009.

Freitas, H. J., Cotta, J. T. B., Oliveira, A. I., \& Gewehr, C. E. (2005). Evaluation of lightning programs upon the performance of white egg layers. Ciência e Agrotecnologia 29 (2), 424-428. 10.1590/S1413-70542005000200021

Gomes, N. M., Faria, M. A. de, Silva, A. M., Mello, C. R. de., \& Viola, M. R. (2007). Spatial variability of physical attributes of soil associated with use and occupation of landscape. Revista Brasileira de Engenharia Agrícola e Ambiental, 11 (4), 427-435. 10.1590/S1415-43662007000400013.

González-Garcia, S., Gomez-Fernández, Z., Dias, A. C., Feijoo, G., Moreira, M. T., \& Arroja, L. (2014). Life cycle assessment of broiler chicken production: a Portuguese case study. Journal of Cleaner Production, 74 (1), 125-134. 10.1016/j.jclepro.2014.03.067

Gous, R. M., \& Cherry, P. (2004). Effects of body weight at, and lighting regimen and growth curve to, 20 weeks on laying performance in broiler breeders. British Poultry Science, 45, 445-452. 10.1080/00071660400001256

Instituto Nacional de Metrologia, Normalização e Qualidade Industrial. INMETRO. (2015). Programa Brasileiro de Etiquetagem - PBE. Tipo de Equipamento: Lâmpadas de Uso Doméstico - Linha Incandescentes - 127V e 220V. Folheto. http://www.inmetro.gov.br/consumidor/tabelas.asp

Kristensen, H. H., Prescott, N. B., Perry, G. C., Ladewing, J., Ersboll, A. K., Overvad, K. C., \& Wathes, C. M. (2007). The behavior of broiler chickens in different light sources and illuminances. Applied Animal Behaviour Science, 103 (1-2), 75-89. doi: 10.1016/j.applanim.2006.04.017

Lewis, P. D., Backhouse, D., \& Gous, R. M. (2004). Photoperiod and oviposition time in broiler breeders. British Poultry Science, 45, 561-564. $10.1080 / 00071660412331286244$

Lewis, P. D., Ghebremariam, W., \& Gous, R. M. (2007). Illuminance and UV-A exposure during rearing affects egg production in broiler breeders transferred to open-sided adult housing. British Poultry Science, 48 (4), 424-429. 10.1080/00071660701543105

Mendes, A. S., Reffati, R., Restelatto, R., \& Paixão, S. J. (2010). Visão e iluminação na avicultura moderna. Revista Brasileira de Agrociência, 16 (1-4), 5-13. 10.18539/cast.v16i1-4.2001

Mendes, A. S., Refatti, R., \& Possenti, J. C. (2008). A iluminação na avicultura. Avicultura Industrial, 10, 34-40.

Miragliotta, M. Y., Nääs, I. A., Manzione, R. L., \& Nascimento, F. F. (2006). Spatial analysis of stress conditions inside broiler house under tunnel ventilation. Scientia Agricola, 63 (5), 426-432. 10.1590/S0103-90162006000500002.

Moraes, D. T., Lara, L. J. C., Baião, N. C., Cançado, S. V., Gonzalez, M. L., Aguilar, C. A. L., \& Lana A. M. Q. (2008). Effect of lighting programs on performance, carcass yield, and immunological response of broiler chickens. Arquivo Brasileiro de Medicina Veterinária e Zootecnia, 60 (1), 201-208. 10.1590/S0102-09352008000100028

Olanrewaju, H. A. J. P., Thaxton, W. A., Dozier I. J., Purswell, J., Roush, W. B., \& Branton, S. L. (2006). A review of lighting programs for broiler production. International Journal of Poultry Science, 5 (4), 301-308. 10.3923/ijps.2006.301.308

Paulino, M. A. de O., Figueiredo, F. P., Fernandes, R. C., Maia, J. T. de L. S., Guilherme, D. de O., \& Barbosa, F. S., (2009). Evaluation of the uniformity and efficiency of water application in systems of irrigation for sprinkle irrigation. Revista Brasileira de Agricultura Irrigada, 3 (2), 48-54. 10.7127/rbai.v3n200011

Pereira, P. A., Yanagi Junior, T., Silva, J. P., Lima, R. R. de, Campos, A. T., \& Abreu, L. H. P. (2012). Technical evaluation of artificial ligthing systems for broiler houses. Engenharia Agrícola, 32 (6), 1011-1024. 10.1590/S0100-69162012000600002.

Rierson, R. del. (2011). Broiler preference for light color and feed form, and the effect of light on growth and performance of broiler chicks. Master thesis. Kansas State University Manhattan, Kansas. 71p.

Rutz, F., \& Bermudez, V. L. (2004). Fundamentos de um programa de luz para frangos de corte. In: Mendes, A. A., Nääs, I. A., \& Macari, M. (Ed.). Produção de frangos de corte. Campinas: FACTA. p. 157-168. 
Research, Society and Development, v. 10, n. 12, e170101220155, 2021

(CC BY 4.0) | ISSN 2525-3409 | DOI: http://dx.doi.org/10.33448/rsd-v10i12.20155

Vercellino, R. A., Moura, D. J., Nääs, I. A., Maia, A. P. A., Medeiros, B. B. L., Salgado, D. D. A., \& Carvalho, T. R. M. (2013). The Influence of side-curtain color on broiler chick behavior. Brazilian Journal of Poultry Science, 15 (3), 169-286. 10.1590/S1516-635X2013000300002

Vieira, S. R. (2000). Geoestatística em estudos de variabilidade espacial do solo. In: Novais, R. F., Alvares, V. H., \& Schaefer, C. E. G. R. Tópicos em ciência do solo. Viçosa: Sociedade Brasileira de Ciência do Solo 1: 1-53.

Yanagi Júnior, T., Amara, A. G., Teixeira, V. H., \& Lima, R. R. (2011). Spatial characterization of thermoacoustic and luminance environment in commercial broiler chicken house. Engenharia Agrícola, 31 (1), 1-12. 10.1590/S0100-69162011000100001 